\title{
Pengaruh Tunjangan Sertifikasi dan Komitmen Pada Tugas Terhadap Prestasi Kerja Guru
}

\author{
Evi Anggraini, Edi Harapan, Tahrun \\ Universitas PGRI, Palembang, Sumatera Selatan, Indonesia
}

corresponding author: Evi Anggraini (e-mail: eviaggraini2345@gmail.com)

\begin{abstract}
Abstrak: Penelitian ini bertujuan untuk menguji 1) Ada atau tidak pengaruh tunjangan sertifikasi terhadap prestasi kerja guru di SMA Negeri Tanjung Raja, 2) Ada atau tidak pengaruh komitmen pada tugas terhadap prestasi kerja guru Di SMA Negeri Tanjung Raja, 3) Ada atau tidak pengaruh tunjangan sertifikasi dan komitmen pada tugas terhadap Prestasi Kerja Di SMA Negeri Tanjung Raja. Penelitian ini menggunakan metode kuantitatif. Pengumpulan data dilakukan dengan angket, dan dokumentasi. Data dianalisis secara deskriptif dengan menggunakan program SPSS versi 16 for windows. Dari hasil penelitian dapat disimpulkan bahwa 1) Terdapat pengaruh tunjangan sertifikasi $\left(\mathrm{X}_{1}\right)$ terhadap prestasi kerja $(\mathrm{Y}), 2)$ Terdapat pengaruh komitmen pada tugas $\left(\mathrm{X}_{2}\right)$ terhadap prestasi kerja guru (Y), dan 3) Ada pengaruh sertifikasi $\left(\mathrm{X}_{1}\right)$, dan komitmen pada tugas $\left(\mathrm{X}_{2}\right)$ terhadap prestasi kerja guru $(\mathrm{Y})$ di SMA Negeri Tanjung Raja. Implikasi dalam penelitian ini adalah: 1) Sertifikasi guru merupakan sebuah program di mana guru akan dimonitoring dan diuji secara berkala dengan menggunakan alat uji yang telah ditetapkan pemerintah. Sertifikasi guru akan menciptakan mampu sumber daya pengajar yang semakin baik. 2) Komitmen pada tugas yang dimiliki oleh setiap guru sangat penting karena dengan suatu komitmen seorang guru dapat menjadi lebih bertanggung jawab terhadap pekerjaannya. Guru yang memiliki suatu komitmen, akan bekerja secara optimal sehingga dapat mencurahkan perhatian, pikiran, tenaga dan waktunya untuk pekerjaannya, sehingga apa yang sudah dikerjakannya sesuai dengan yang diharapkan oleh sekolah. 3) Prestasi kerja guru merupakan kontribusi yang diberikan oleh seorang guru terhadap tugas dan fungsinya di melalui totalitas kemampuan yang dimilikinya untuk mencapai tujuan pendidikan nasional.
\end{abstract}

Kata kunci: tunjangan sertifikasi, komitmen pada tugas, prestasi kerja

\section{The Influence of Certification Allowances and Commitment to Work to Teachers' Performance}

\begin{abstract}
This study aims to examine 1) The effect of certification allowances on teachers' performance in Tanjung Raja State High School, 2) The effect of commitment to work for teachers' performance in Tanjung Raja State High School, 3) Effect of certification allowances and commitment on work on teacher performance in SMA Negeri Tanjung Raja. This research used quantitative methods. Data collection is done by questionnaire and documentation. Data were analyzed descriptively using SPSS version 16 for windows. From the results of the study it can be concluded that 1) There is an influence of certification allowance $\left(X_{1}\right)$ on teachers' performance $\left.(Y), 2\right)$ There is an influence of commitment to work $\left(X_{2}\right)$ on teachers' performance $(Y)$, and 3) There is an influence of
\end{abstract}


certification $\left(X_{1}\right)$, and commitment to work $\left(X_{2}\right)$ to teachers' performance $(Y)$ in Tanjung Raja State High School. The implications in this study are: 1) Teacher certification is a program in which teachers will be monitored and tested periodically by using government-determined test equipment. Teacher certification will create able increasingly better teaching resources. 2) Commitment to the tasks held by each teacher is essential because, with a commitment, a teacher can become more responsible for his work. Teachers who commit will work optimal so they can devote their attention, thoughts, energy and time to their work so that what they have done is in line with what is expected by the school. 3) Teacher performance is a contribution given by a teacher to his tasks and functions through the totality of his abilities to achieve national education goals

Keywords: certification allowance, commitment, performance.

\section{PENDAHULUAN}

Kebijakan sertifikasi bagi guru dan dosen memang suatu langkah yang strategis untuk dapat meningkatkan mutu pendidikan di Indonesia. Secara formal, Undang-Undang Republik Indonesia Nomor 20 Tahun 2003 tentang Sistem Pendidikan Nasional, UndangUndang Republik Indonesia Nomor 14 Tahun 2005 tentang Guru dan Dosen dan Peraturan Pemerintah Nomor 19 tahun 2005 tentang Standar Nasional Pendidikan menyatakan bahwa guru adalah tenaga profesional. Sebagai tenaga profesional, guru dipersyaratkan memiliki kualifikasi akademik S-1 (strata satu) atau D-4 (diploma empat) dalam bidang yang relevan dengan mata pelajaran yang diampunya dan menguasai kompetensi sebagai agen pembelajaran.

Terkait dengan sertifikasi guru, pemerintah memikirkan kesejahteraan guru sebagai salah satu konsekuensi yang harus ditanggung pemerintah sehubungan dengan sertifikasi guru tersebut, maka dari $20 \%$ Anggaran Pendapatan dan Belanja Negara (APBN) diperuntukkan bagi pendidikan seperti yang diamanatkan dalam amandemen Undang-Undang Dasar 1945 dan tertuang dalam pasal 49 UU No 20 Tahun 2003 tentang Sistem Pendidikan Nasional. Mengingat peranan guru dalam proses pendidikan begitu penting, sehingga sangat diharapkan guru dapat menjalankan tugas dan kewajiban sesuai dengan tuntutan profesinya. Sebagai sebuah profesi, profesionalitas merupakan sesuatu yang harus dipenuhi oleh guru.

Profesionalitas merupakan konsekuensi logis atas profesi guru. Artinya setiap guru harus dapat berbuat, berkata, dan bersikap sebagai seorang profesional dengan segala konsekuensi yang harus ditanggungnya (Saroni, 2011: 98). Hal ini tercantum dalam Undang-Undang Republik Indonesia Nomor 14 Tahun 2005 tentang Guru dan 
Dosen pada Pasal 1 juga telah menyebutkan bahwa guru adalah pendidik profesional dengan tugas utama mendidik, mengajar, membimbing, mengarahkan, melatih, menilai, dan mengevaluasi peserta didik pada pendidikan anak usia dini, jalur pendidikan formal, pendidikan dasar, dan pendidikan menengah.

Sertifikasi guru merupakan salah satu bentuk perhatian pemerintah terhadap keberadaan guru sebagai sumber daya yang mempengaruhi keberlangsungan pendidikan di sekolah. Pemerintah Republik Indonesia melalui Kementerian Pendidikan Nasional mulai menyelenggarakan program sertifikasi guru pada tahun 2007, dengan tujuan untuk menentukan kelayakan guru dalam melaksanakan tugas sebagai pendidik profesional, meningkatkan proses dan hasil pembelajaran, meningkatkan kesejahteraan guru, meningkatkan martabat guru, dan meningkatkan profesionalitas guru (Depdiknas, 2009: 5). Program sertifikasi guru pada dasarnya memberikan harapan yang tinggi, karena kedepannya guru diharapkan dapat menunjukkan profesionalitas kerja untuk menghasilkan output (lulusan) pendidikan yang berkualitas.

Dalam Undang-Undang Republik Indonesia Nomor 14 tahun 2005 tentang Guru dan Dosen disebutkan beberapa ketentuan mengenai sertifikasi guru yaitu sebagai berikut: Pasal 1 Ayat 11: sertifikasi adalah proses pemberian sertifikat pendidik untuk guru dan dosen. Pasal 8 menyebutkan bahwa guru wajib memiliki kualifikasi akademik, kompetensi, sertifikat pendidik, sehat jasmani dan rohani, serta memiliki kemampuan untuk mewujudkan tujuan pendidikan nasional. Pasal 11 ayat 1 disebutkan sertifikat pendidik sebagaimana dimaksud dalam Pasal 8 diberikan kepada guru yang telah memenuhi persyaratan. Pasal 16: pemerintah memberikan tunjangan profesi kepada guru yang telah memiliki sertifikat pendidik yang diangkat oleh penyelenggara pendidikan dan/atau satuan pendidikan yang diselenggarakan oleh masyarakat.

Pada SMA Tanjung Raja jumlah guru yang memperoleh sertifikasi yaitu sebanyak 20 orang atau 55\% dari jumlah guru yang ada. Sebagian besar guru sudah sertifikasi dan menerima tunjangan profesi sebesar $100 \%$ dari gaji pokok, dan kinerja guru meningkat. Jika ditinjau dari hasil Ujian Nasional (UN), rata-rata nilai UN siswa kelas XII belum mangalami peningkatan secara signifikan. Secara eksplisit dinyatakan bahwa faktorfaktor yang mempengaruhi keberhasilan proses pembelajaran di dalam kelas diantaranya adalah kompetensi guru, metode pembelajaran yang dipakai, kurikulum, sarana dan prasarana, serta lingkungan pembelajaran baik lingkungan alam, sosial dan budaya. 
Dapat diartikan di sini bahwa lingkungan sosial pembelajaran di kelas maupun di sekolah (kantor guru dan staf tata usaha) mempunyai pengaruh baik langsung maupun tak langsung terhadap proses belajar mengajar.

Prestasi kerja guru akan baik jika guru telah melakukan unsur-unsur yang terdiri dari kesetiaan dan komitmen yang tinggi pada tugas mengajar, menguasai dan mengembangkan bahan pelajaran, kedisiplinan dalam mengajar dan tugas lainnya, kreativitas dalam pelaksanaan pengajaran, kerja sama dengan semua warga sekolah, kepemimpinan yang menjadi panutan siswa, kepribadian yang baik, jujur dan objektif dalam membimbing siswa, serta tanggung jawab terhadap tugasnya. Oleh karena itu tugas kepala sekolah selaku manajer adalah melakukan penilaian terhadap kinerja guru. Penilaian ini penting untuk dilakukan mengingat fungsinya sebagai alat motivasi bagi pimpinan kepada guru maupun bagi guru itu sendiri.

Keberhasilan sebuah lembaga pendidikan dipengaruhi oleh keberadaan guru di sekolah tersebut. Profesionalitas guru dalam arti komitmen kerja guru yang tinggi dalam bekerja juga turut memberikan kontribusi pada keberhasilan pembelajaran. Sementara komitmen guru akan tumbuh jika guru merasa kepuasan kerjanya terpenuhi. Apabila kepuasan kerja terjadi pada guru, maka ia akan terdorong untuk bekerja lebih giat dan berusaha membuat organisasinya berkembang. Berdasarkan hal ini, maka peneliti sangat tertarik untuk mengetahui seberapa besar sertifikasi dapat mempengaruhi komitmen dan kepuasan kerja guru. Sebab, komitmen dan kepuasan kerja dalam diri seorang guru sangat menentukan kinerjanya untuk keberhasilan pendidikan.

Gambaran prestasi kerja guru dapat dicermati dari berbagai kajian hasil maupun dampak sertifikasi guru. Hasil kajian yang dilakukan Ditjen Peningkatan Mutu Pendidik dan Tenaga Kependidikan (PMPTK) tahun 2018 menunjukkan bahwa guru yang telah mengikuti (lolos) sertifikasi ternyata tidak serta merta menunjukkan peningkatan prestasi kerja, meski lolos sertifikasi, nilai kompetensi guru rata-rata di angka kisaran 52-64 persen. Kajian juga menemukan bahwa motivasi guru untuk segera mengikuti sertifikasi bukanlah semata-mata untuk meningkatkan kompetensi, melainkan yang lebih menonjol adalah motivasi finansial berupa tunjangan profesi. Temuan lain hasil survei yang dilakukan Persatuan Guru Republik Indonesia (PGRI) mengenai dampak sertifikasi profesi guru terhadap kinerja guru menunjukkan bahwa prestasi kerja guru yang sudah lolos sertifikasi masih belum memuaskan. 
Motivasi kerja yang tinggi justru ditunjukkan oleh guru-guru di berbagai jenjang pendidikan yang belum lolos sertifikasi, dengan harapan segera mendapat sertifikasi berikut uang tunjangan profesi. Selain itu, peningkatan prestasi kerja yang diharapkan dari guru yang sudah bersertifikat seperti perubahan pola kerja, motivasi kerja, pembelajaran, atau peningkatan diri dinilai masih tetap sama atau hanya sedikit. Guruguru yang sudah bersertifikat sudah mulai enggan mengikuti kegiatan akademik yang menunjang peningkatan profesionalisme guru.

Berdasarkan pemaparan di atas ternyata terdapat beberapa kendala yang dihadapi dalam pelaksanaan sertifikasi bagi guru yang sejak lama telah diberlakukan di Indonesia. Fenomena-fenomena tersebut menarik untuk diteliti sehingga penelitian ini dilakukan untuk mengetahui lebih dalam tentang Pengaruh Tunjangan Sertifikasi Guru dan Komitmen pada Tugas terhadap Prestasi Kerja di SMA Negeri Tanjung Raja.

\subsection{Tunjangan sertifikasi guru}

Sertifikasi merupakan sarana atau instrumen untuk mencapai suatu tujuan, bukan tujuan itu sendiri. Perlu ada kesadaran dan pemahaman dari semua pihak bahwa sertifikasi adalah sarana untuk menuju kualitas. Demikian pula kalau guru mengikuti sertifikasi, tujuan utama bukan untuk mendapatkan tunjangan profesi, melainkan untuk dapat menunjukkan bahwa yang bersangkutan telah memiliki kompetensi sebagaimana disyaratkan dalam standar kompetensi guru. Tunjangan profesi adalah konsekuensi logis yang menyertai adanya kemampuan yang dimaksud. Dengan menyadari hal ini maka guru tidak akan mencari jalan lain guna memperoleh sertifikat profesi kecuali mempersiapkan diri dengan belajar yang benar untuk menghadapi sertifikasi. Berdasarkan hal tersebut, maka sertifikasi akan membawa dampak positif, yaitu meningkatnya kualitas guru.

Sertifikasi menurut Marselus (2011: 68) adalah proses pemberian sertifikat kepada suatu objek tertentu (orang, barang, atau organisasi) yang menandakan bahwa objek tertentu layak atau sesuai dengan kriteria, atau standar tertentu. Dalam hal ini sertifikasi diartikan sebagai suatu jaminan mutu kepada pengguna objek tersebut. Guru merupakan seseorang yang bertugas dan memberikan pelayanan kepada masyarakat dalam bidang pendidikan (organisasi sekolah), sehingga perlu ada suatu pembuktian ataupun uji kelayakan. 
Terkait dengan hal ini, National Commision on Educational Services dalam (Mulyasa, 2013: 34) memberikan pengertian sertifikasi guru secara umum, Certification is a procedure whereby the state evaluates and reviews a teacher candidate's credentials and provides him or her a license to teach. Definisi ini mengandung pengertian bahwa, sertifikasi merupakan serangkaian prosedur untuk menentukan apakah seorang guru layak diberikan izin dan kewenangan untuk mengajar. Kegiatan sertifikasi profesi guru meliputi peningkatan kualifikasi dan uji kompetensi. Uji kompetensi dilakukan melalui tes tertulis untuk menguji kompetensi profesional dan pedagogi, dan penilaian kinerja untuk menguji kompetensi sosial dan kepribadian.

Pendapat lain juga dikemukakan oleh Masnur Muslich (2009: 2), sertifikasi adalah proses pemberian sertifikat pendidik kepada guru yang telah memenuhi persyaratan tertentu, yang memiliki kualifikasi akademik, kompetensi, sehat jasmani, dan rohani serta memiliki kemampuan mewujudkan tujuan pendidikan nasional, yang dibarengi dengan peningkatan kesejahteraan yang layak. Sasaran utama program sertifikasi adalah menjadikan guru sebagai pendidik profesional yang memiliki kinerja yang baik. Sehingga mampu menghasilkan sumber daya manusia yang bermutu tinggi karena mereka terlibat langsung dalam proses pendidikan.

\subsection{Komitmen terhadap tugas}

Komitmen bisa dibilang sebagai sebuah janji pada diri sendiri untuk mendapatkan harga diri dengan menyelesaikan tugas yang telah diberi. Maka dari itu, ketika seseorang sudah berjanji maka tidak ada alasan lagi untuk tidak menepatinya. Dia akan melakukan segala macam hal untuk dapat memenuhi janjinya tersebut. Akan tetapi yang perlu diingat bahwa cara untuk mendapatkan nilai komitmen, harus tetap pada prosedur yang ada. Dalam arti lain, komitmen adalah kesesuaian kata yang terucap dengan hati yang bergerak disertai dengan tindakan nyata untuk mendapatkan hasil yang maksimal dari janji tersebut. Jadi komitmen bukan hanya rasa setia atau mengabdi akan tetapi tentang apa yang dilakukan untuk kesetiaan dan pengabdian tersebut.

Istilah komitmen memiliki berbagai macam definisi maupun cara pengukuran. Greenberg (2011: 231) mengemukakan bahwa commitment is the extent to which an individual identifies and is involved with his or her organization and/or is unwilling to leave it. Dalam hal ini komitmen menggambarkan seberapa jauh seseorang mengidentifikasikan dan melibatkan diri pada organisasinya dan keinginan untuk tetap 
tinggal di organisasi itu. Senada dengan definisi tersebut, Colquitt, Lepine \& Wesson (2015: 83) mengemukakan bahwa commitment is the desire on the part of an employee to remain a member of the organization. Definisi ini menunjukkan bahwa komitmen merupakan keinginan pada seseorang (anggota) untuk tetap menjadi bagian dari organisasi.

Keinginan tersebut berarti bahwa adanya kesediaan dari seseorang untuk melakukan apapun bagi organisasinya. Senada dengan hal ini Kreitner \& Kinicki (2013: 163) mengatakan commitment is an agreement to do something for yourself, another individual, group, or organization. Hal ini berarti bahwa komitmen merupakan kesepakatan dalam diri seseorang melakukan sesuatu baik untuk diri sendiri, orang lain, kelompok, ataupun organisasi. Komitmen menjadi penting di era sekarang karena kecenderungan generasi muda yang serba instan membuat komitmen terhadap organisasi relatif cepat pudar

Berdasarkan beberapa definisi di atas terdapat beberapa hal yang memaknai suatu komitmen yaitu kesadaran, keinginan, dan kesepakatan dalam diri seseorang untuk berusaha dengan sungguh-sungguh sebagai bentuk keterikatan dirinya dalam organisasi dan mempertahankan keanggotaan di dalam organisasi. Komitmen merupakan orientasi hubungan antara seseorang dan organisasinya. Orientasi hubungan tersebut mengakibatkan seseorang (anggota organisasi) atas kehendak sendiri bersedia memberikan sesuatu, dan sesuatu yang diberikan itu menggambarkan dukungannya bagi pencapaian tujuan organisasi. Guru merupakan seseorang yang harus berdedikasi pada bidang pendidikan. Dalam lingkup yang lebih kecil dedikasi seorang guru yaitu pada organisasi sekolah tempat ia bekerja.

\subsection{Prestasi kerja guru}

Prestasi kerja disebut sebagai kinerja atau dalam bahasa inggris disebut dengan Performance. Pada prinsipnya, ada istilah lain yang lebih menggambarkan pada prestasi dalam bahasa Inggris yaitu kata Achievement. Tetapi karena kata tersebut berasal dari kata "to achieve" yang berarti "mencapai", maka dalam bahasa Indonesia sering diartikan menjadi pencapaian atau "apa yang dicapai”. Sebagaimana yang diungkapkan Mangkunegara (2009:67) prestasi kerja merupakan hasil kerja secara kualitas dan kuantitas yang dicapai oleh seorang pegawai dalam melaksanakan tugasnya sesuai 
tanggung jawab yang diberikan kepadanya. Dengan demikian seseorang dikatakan berprestasi kerja jika dilihat hasil kerja/kinerjanya sesuai dengan tujuan perusahaan.

Selanjutnya menurut Ridwan (2014:94) Prestasi kerja adalah suatu hasil kerja yang dicapai oleh seorang dalam melaksanakan tugas-tugas yang dibebankan kepadanya yang didasarkan atas kecakapan, pengalaman, kesungguhan, serta waktu. Prestasi kerja merupakan suatu hal yang sangat penting artinya bagi suatu organisasi, sebab prestasi kerja mencerminkan hasil yang telah dicapai oleh pegawai selama bekerja pada organisasi tersebut. Dari beberapa pendapat sebelumnya dapat disimpulkan bahwa prestasi kerja adalah kesuksesan atau hasil yang dicapai oleh seseorang dalam melaksanakan pekerjaannya sesuai dengan tanggung jawab, kecakapan, pengalaman, kesungguhan, serta waktu yang diberikan kepadanya dan harus dipertanggung jawabkan hasilnya.

\section{METODE PENELITIAN}

Jenis penelitian ini menggunakan pendekatan kuantitatif. Penelitian kuantitatif adalah suatu jenis penelitian yang pada dasarnya menggunakan prinsip deduktif-induktif. Pendekatan ini berangkat dari suatu kerangka teori, gagasan para ahli, maupun pemahaman peneliti berdasarkan pengalamannya, kemudian dikembangkan menjadi permasalahan-permasalahan beserta pemecahannya yang diajukan untuk memperoleh pembenaran (verifikasi) atau penilaian dalam bentuk dukungan data empiris di lapangan. Adapun desain penelitian yang digunakan dalam penelitian ini dengan menggunakan penelitian deskripsi analitik. Metode pendekatan cross sectional, yaitu suatu penelitian untuk mempelajari hubungan sebab akibat antara dua variabel pada suatu situasi atau sekelompok subyek yang dilakukan untuk melihat hubungan antara variabel yang satu dengan yang lain, dengan cara pendekatan, observasi atau pengumpulan data sekaligus dalam waktu yang bersamaan.

\subsection{Sampel penelitian}

Sampel merupakan bagian dari elemen-elemen populasi yang hendak diteliti. Adapun ide dasar dari pengambilan sampel adalah bahwa dengan menyeleksi bagian dari elemenelemen populasi dapat merekam kecenderungan secara umum variabel tersebut. Teknik sampling merupakan teknik pengambilan sampel dalam penelitian. Di mana yang digunakan pada penelitian ini adalah teknik simple random sampling, hal ini memungkinkan setiap unit sampling sebagai unsur populasi memperoleh peluang yang 
sama untuk menjadi sampel. Penulis menggunakan teknik simple random sampling karena yang menjadi populasi dalam penelitian ini tidak terlalu besar yaitu dengan sampling sebanyak 51 orang. Hal ini dapat dilihat pada tabel di bawah ini.

Tabel 1.Sampel Penelitian

\begin{tabular}{rlc}
\hline No & Nama Sekolah & Jumlah Guru \\
\hline 1 & SMA Negeri 1 Tanjung Raja & 18 \\
2 & SMA Negeri 2 Tanjung Raja & 18 \\
3 & SMA Negeri 3 Tanjung Raja & 15 \\
\hline & Total & 51 \\
\hline
\end{tabular}

\subsection{Teknik pengumpulan data}

Pengumpulan data dilaksanakan dengan menggunakan angket (kuesioner) dan dokumentasi. Kuesioner yang digunakan oleh peneliti sebagai instrumen penelitian adalah dengan kuesioner tertutup. Instrument kuesioner harus diukur validitas dan reabilitas datanya sehingga penelitian tersebut menghasilkan data yang valid dan reliabel. Instrumen yang digunakan untuk mengukur variabel penelitian ini dengan menggunakan skala likert 5 poin.

\subsection{Teknik analisis data}

Uji asumsi klasik pada penelitian ini meliputi; 1) uji normalitas dilakukan untuk mengetahui apakah residual dari populasi yang digunakan terdistribusi normal atau tidak; 2) Uji homogenitas data diperlukan untuk membuktikan persamaan variasi kelompok yang membentuk sampel; 3) Multikolinearitas adalah korelasi linear yang "perfect" atau eksak di antara variabel penjelas yang dimasukkan ke dalam model, jika antara variabel independen terjadi multikolineritas, maka nilai koefisien regresi tidak dapat ditentukan hasilnya karena dari formula OLS rumus regresi diturunkan dari asumsi data tertentu.

Adapun analisis data yang digunakan meliputi analisis korelasi, analisis regresi, uji regresi parsial (uji t), dan uji regresi berganda (uji f). Analisis korelasi mencangkup analisis korelasi linier sederhana bertujuan untuk mengetahui apakah ada hubungan antara dua variabel dan juga keeratan korelasinya, dan analisis korelasi ganda merupakan angka yang menunjukkan arah dan kuatnya hubungan antara dua variabel independen secara bersama-sama atau lebih dengan satu variabel dependen. Sedangkan analisis regresi mencangkup regresi linier sederhana dapat diartikan sebagai suatu uji yang menyangkut sebuah variabel independen dan variabel dependen, dan regresi linier ganda 
merupakan suatu alat analisis peramalan nilai pengaruh variabel bebas atau lebih terhadap variabel terikat untuk membuktikan ada atau tidaknya hubungan fungsi atau hubungan kausal antara dua variabel bebas atau lebih. Uji t digunakan untuk menganalisis hasil estimasi statistik nilai parameter a dan $b$, apakah nilai $a$, dan $b$ dapat dipercaya atau berpengaruh secara signifikan. Sedangkan uji f tujuannya adalah apakah variabel independen secara bersama-sama (simultan) mampu menjelaskan variabel dependen.

\section{HASIL PENELITIAN}

\subsection{Deskripsi data variabel tunjangan sertifikasi guru $\left(\mathrm{X}_{1}\right)$}

Tabel 3.1 di bawah ini merupakan distribusi frekuensi variabel Tunjangan Sertifikasi Guru $\left(\mathrm{X}_{1}\right)$ pada setiap item untuk masing-masing indikator yang ada. Berdasarkan tabel 2, dapat diketahui bahwa nomor butir soal pada angket sebanyak 19 item mulai nomor 1 - 19, sedangkan jawaban responden yang terdiri dari 5 opsi yaitu nilai 1 merupakan jawaban sangat tidak setuju, nilai 2 jawaban tidak setuju, nilai 3 jawaban ragu-ragu, nilai 4 jawaban setuju dan nilai 5 jawaban sangat setuju. Persentase tabel di atas diperoleh dari jumlah jawaban angket dibagi total responden dikali 100\%, sehingga diperoleh persentase jawaban tiap item. Tabel di atas terlihat jelas bahwa tunjangan profesi guru pada indikator prinsip sertifikasi menunjukkan $1 \%$ responden menjawab sangat tidak setuju, 9\% menjawab tidak setuju, 17\% menjawat ragu-ragu, 31\% menjawab setuju dan $42 \%$ menjawab sangat setuju.

Pada indikator tujuan sertifikasi menunjukkan $1 \%$ responden menjawab sangat tidak setuju, $10 \%$ responden menjawab tidak setuju, 17\% responden menjawab ragu-ragu, $31 \%$ responden menjawab setuju dan $41 \%$ menjawab sangat setuju. Pada indikator manfaat sertifikasi menunjukkan $2 \%$ menjawab sangat tidak setuju, $11 \%$ menjawab tidak setuju, 14\% menjawab ragu-ragu, 29\% menjawab setuju dan $44 \%$ menjawab sangat setuju.

\subsection{Deskripsi data variabel komitmen pada tugas $\left(\mathrm{X}_{2}\right)$}

Variabel komitmen pada tugas juga dijawab oleh responden dengan lima opsi jawaban untuk mengetahui persentase jawaban para responden. Tabel 3 merupakan distribusi frekuensi variabel perolehan variabel komitmen pada tugas $\left(\mathrm{X}_{2}\right)$. 
Tabel 2. Distribusi Frekuensi Variabel Tunjangan Sertifikasi Guru (X $\left.\mathrm{X}_{1}\right)$

\begin{tabular}{|c|c|c|c|c|c|c|c|c|c|c|c|c|}
\hline \multicolumn{13}{|c|}{ Tunjangan Sertifikasi Guru } \\
\hline \multicolumn{6}{|c|}{ Jawaban Responden } & \multirow[b]{2}{*}{ Frekuensi } & \multicolumn{5}{|c|}{ Persentase } & \multirow{2}{*}{$\%$} \\
\hline Item & 1 & 2 & 3 & 4 & 5 & & 1 & 2 & 3 & 4 & 5 & \\
\hline \multicolumn{13}{|c|}{ PRINSIP SERTIFIKASI } \\
\hline 1 & 1 & 2 & 11 & 16 & 21 & 51 & 2 & 4 & 22 & 31 & 41 & 100 \\
\hline 2 & 0 & 2 & 7 & 15 & 27 & 51 & 0 & 4 & 14 & 29 & 53 & 100 \\
\hline 3 & 2 & 7 & 10 & 15 & 17 & 51 & 4 & 14 & 20 & 29 & 33 & 100 \\
\hline 4 & 0 & 7 & 4 & 12 & 28 & 51 & 0 & 14 & 8 & 24 & 55 & 100 \\
\hline 5 & 1 & 2 & 12 & 20 & 16 & 51 & 2 & 4 & 24 & 39 & 31 & 100 \\
\hline 6 & 1 & 8 & 2 & 18 & 22 & 51 & 2 & 16 & 4 & 35 & 43 & 100 \\
\hline 7 & 0 & 4 & 14 & 13 & 20 & 51 & 0 & 8 & 27 & 25 & 39 & 100 \\
\hline Total & 5 & 32 & 60 & 109 & 151 & 357 & 1 & 9 & 17 & 31 & 42 & 100 \\
\hline \multicolumn{13}{|c|}{ TUJUAN SERTIFIKASI } \\
\hline 8 & 2 & 4 & 9 & 17 & 19 & 51 & 4 & 8 & 18 & 33 & 37 & 100 \\
\hline 9 & 0 & 5 & 9 & 15 & 22 & 51 & 0 & 10 & 18 & 29 & 43 & 100 \\
\hline 10 & 0 & 3 & 8 & 19 & 21 & 51 & 0 & 6 & 16 & 37 & 41 & 100 \\
\hline 11 & 0 & 10 & 5 & 13 & 23 & 51 & 0 & 20 & 10 & 25 & 45 & 100 \\
\hline 12 & 1 & 6 & 11 & 18 & 15 & 51 & 2 & 12 & 22 & 35 & 29 & 100 \\
\hline 13 & 0 & 3 & 8 & 15 & 25 & 51 & 0 & 6 & 16 & 29 & 49 & 100 \\
\hline 14 & 0 & 4 & 9 & 15 & 23 & 51 & 0 & 8 & 18 & 29 & 45 & 100 \\
\hline Total & 3 & 35 & 59 & 112 & 148 & 357 & 1 & 10 & 17 & 31 & 41 & 100 \\
\hline \multicolumn{13}{|c|}{ MANFAAT SERTIFIKASI } \\
\hline 15 & 1 & 9 & 6 & 12 & 23 & 51 & 2 & 18 & 12 & 24 & 45 & 100 \\
\hline 16 & 1 & 4 & 7 & 13 & 26 & 51 & 2 & 8 & 14 & 25 & 51 & 100 \\
\hline 17 & 1 & 4 & 11 & 17 & 18 & 51 & 2 & 8 & 22 & 33 & 35 & 100 \\
\hline 18 & 0 & 6 & 5 & 16 & 24 & 51 & 0 & 12 & 10 & 31 & 47 & 100 \\
\hline 19 & 1 & 5 & 7 & 16 & 22 & 51 & 2 & 10 & 14 & 31 & 43 & 100 \\
\hline Total & 4 & 28 & 36 & 74 & 113 & 255 & 2 & 11 & 14 & 29 & 44 & 100 \\
\hline
\end{tabular}

Berdasarkan tabel 3, dapat diketahui bahwa nomor butir soal pada angket sebanyak 19 item mulai dari nomor 1-19, sedangkan jawaban responden terdiri dari 5 opsi yaitu nilai 1 merupakan jawaban sangat tidak setuju, nilai 2 jawaban tidak setuju, nilai 3 jawaban ragu-ragu, nilai 4 jawaban setuju dan nilai 5 jawaban sangat setuju. Persentase tabel di atas diperoleh dari jumlah jawaban angket dibagi total responden dikali $100 \%$, sehingga diperoleh persentase jawaban tiap item.

Dari tabel 3 terlihat jelas komitmen kerja pada indikator keikhlasan dalam bekerja menunjukkan $0 \%$ responden menjawab sangat tidak setuju, $4 \%$ responden menjawab tidak setuju, 15\% menjawab ragu-ragu, 35\% menjawab setuju dan 45\% menjawab sangat setuju. Pada indikator kesadaran dan tanggung jawab jawaban responden adalah 0\% menjawab sangat tidak setuju, $4 \%$ menjawab tidak setuju, $15 \%$ menjawab ragu-ragu, 33\% menjawab setuju dan $47 \%$ menjawab sangat setuju. 
Tabel 3. Distribusi Frekuensi Variabel Komitmen pada Tugas $\left(\mathrm{X}_{2}\right)$

Komitmen pada Tugas

\begin{tabular}{|c|c|c|c|c|c|c|c|c|c|c|c|c|}
\hline \multicolumn{6}{|c|}{ Jawaban Responden } & \multirow[b]{2}{*}{ Frekuensi } & \multicolumn{5}{|c|}{ Persentase } & \multirow{2}{*}{$\%$} \\
\hline Item & 1 & 2 & 3 & 4 & 5 & & 1 & 2 & 3 & 4 & 5 & \\
\hline \multicolumn{13}{|c|}{ Keikhlasan dalam Bekerja } \\
\hline 1 & 0 & 2 & 10 & 19 & 20 & 51 & 0 & 4 & 20 & 37 & 39 & 100 \\
\hline 2 & 0 & 0 & 4 & 21 & 26 & 51 & 0 & 0 & 8 & 41 & 51 & 100 \\
\hline 3 & 0 & 1 & 11 & 15 & 24 & 51 & 0 & 2 & 22 & 29 & 47 & 100 \\
\hline 4 & 0 & 6 & 4 & 15 & 26 & 51 & 0 & 12 & 8 & 29 & 51 & 100 \\
\hline 5 & 0 & 2 & 9 & 20 & 20 & 51 & 0 & 4 & 18 & 39 & 39 & 100 \\
\hline Total & 0 & 11 & 38 & 90 & 116 & 255 & 0 & 4 & 15 & 35 & 45 & 100 \\
\hline \multicolumn{13}{|c|}{ Kesadaran dan Tanggung Jawab } \\
\hline 6 & 0 & 1 & 4 & 20 & 26 & 51 & 0 & 2 & 8 & 39 & 51 & 100 \\
\hline 7 & 0 & 0 & 12 & 15 & 24 & 51 & 0 & 0 & 24 & 29 & 47 & 100 \\
\hline 8 & 0 & 6 & 3 & 16 & 26 & 51 & 0 & 12 & 6 & 31 & 51 & 100 \\
\hline 9 & 0 & 2 & 10 & 16 & 23 & 51 & 0 & 4 & 20 & 31 & 45 & 100 \\
\hline 10 & 0 & 2 & 10 & 18 & 21 & 51 & 0 & 4 & 20 & 35 & 41 & 100 \\
\hline Total & 0 & 11 & 39 & 85 & 120 & 255 & 0 & 4 & 15 & 33 & 47 & 100 \\
\hline \multicolumn{13}{|c|}{ Kepedulian terhadap Peserta Didik } \\
\hline 11 & 0 & 2 & 8 & 14 & 27 & 51 & 0 & 4 & 16 & 27 & 53 & 100 \\
\hline 12 & 0 & 2 & 9 & 18 & 22 & 51 & 0 & 4 & 18 & 35 & 43 & 100 \\
\hline 13 & 0 & 3 & 9 & 12 & 27 & 51 & 0 & 6 & 18 & 24 & 53 & 100 \\
\hline 14 & 0 & 0 & 10 & 19 & 22 & 51 & 0 & 0 & 20 & 37 & 43 & 100 \\
\hline 15 & 0 & 0 & 12 & 12 & 27 & 51 & 0 & 0 & 24 & 24 & 53 & 100 \\
\hline Total & 0 & 7 & 48 & 75 & 125 & 255 & 0 & 3 & 19 & 29 & 49 & 100 \\
\hline \multicolumn{13}{|c|}{ Kedisiplinan dalam Bekerja } \\
\hline 16 & 0 & 4 & 6 & 19 & 22 & 51 & 0 & 8 & 12 & 37 & 43 & 100 \\
\hline 17 & 0 & 5 & 6 & 16 & 24 & 51 & 0 & 10 & 12 & 31 & 47 & 100 \\
\hline 18 & 0 & 0 & 8 & 21 & 22 & 51 & 0 & 0 & 16 & 41 & 43 & 100 \\
\hline 19 & 0 & 0 & 10 & 16 & 25 & 51 & 0 & 0 & 20 & 31 & 49 & 100 \\
\hline Total & 0 & 9 & 30 & 72 & 93 & 204 & 0 & 4 & 15 & 35 & 46 & 100 \\
\hline
\end{tabular}

Pada indikator kepedulian terhadap peserta didik jawaban responden adalah $4 \%$ menjawab sangat tidak setuju, 3\% menjawab tidak setuju, 19\% menjawab ragu-ragu, 29\% menjawab setuju dan $49 \%$ menjawab sangat setuju. Pada indikator kedisiplinan dalam bekerja jawaban responden adalah $4 \%$ menjawab tidak setuju, $15 \%$ menjawab ragu-ragu, $35 \%$ menjawab setuju dan $46 \%$ menjawab sangat setuju.

\subsection{Deskripsi data prestasi kerja (Y)}

Variabel Prestasi Kerja memiliki 19 item pernyataan dengan lima alternatif jawaban yang dipilih oleh responden. Berdasarkan tabel 4, dapat diketahui bahwa nomor butir soal pada angket sebanyak 19 item mulai dari nomor 1-19, sedangkan jawaban responden terdiri dari 5 opsi yaitu nilai 1 merupakan jawaban sangat tidak setuju, nilai 2 jawaban tidak setuju, nilai 3 jawaban ragu-ragu, nilai 4 jawaban setuju dan nilai 5 jawaban sangat setuju. 
Persentase tabel di atas diperoleh dari jumlah jawaban angket dibagi total responden dikali $100 \%$, sehingga diperoleh persentase jawaban tiap item.

Tabel 4. Distribusi Frekuensi Variabel Prestasi Kerja (Y)

\begin{tabular}{|c|c|c|c|c|c|c|c|c|c|c|c|c|}
\hline \multicolumn{13}{|c|}{ Prestasi Kerja } \\
\hline \multicolumn{6}{|c|}{ Jawaban Responden } & & \multicolumn{5}{|c|}{ Persentase } & \multirow{2}{*}{$\%$} \\
\hline Item & 1 & 2 & 3 & 4 & 5 & Frekuensi & 1 & 2 & 3 & 4 & 5 & \\
\hline \multicolumn{13}{|c|}{ Kualitas Kerja } \\
\hline 1 & 0 & 2 & 9 & 29 & 11 & 51 & 0 & 4 & 18 & 57 & 22 & 100 \\
\hline 2 & 0 & 10 & 1 & 27 & 13 & 51 & 0 & 20 & 2 & 53 & 25 & 100 \\
\hline 3 & 0 & 10 & 1 & 18 & 22 & 51 & 0 & 20 & 2 & 35 & 43 & 100 \\
\hline 4 & 0 & 0 & 13 & 28 & 10 & 51 & 0 & 0 & 25 & 55 & 20 & 100 \\
\hline 5 & 0 & 0 & 8 & 21 & 22 & 51 & 0 & 0 & 16 & 41 & 43 & 100 \\
\hline Total & 0 & 22 & 32 & 123 & 78 & 255 & 0 & 9 & 13 & 48 & 31 & 100 \\
\hline \multicolumn{13}{|c|}{ Kuantitas Kerja } \\
\hline 6 & 0 & 1 & 10 & 25 & 15 & 51 & 0 & 2 & 20 & 49 & 29 & 100 \\
\hline 7 & 0 & 9 & 1 & 6 & 35 & 51 & 0 & 18 & 2 & 12 & 69 & 100 \\
\hline 8 & 0 & 4 & 21 & 17 & 9 & 51 & 0 & 8 & 41 & 33 & 18 & 100 \\
\hline 9 & 0 & 1 & 7 & 30 & 13 & 51 & 0 & 2 & 14 & 59 & 25 & 100 \\
\hline Total & 0 & 15 & 39 & 78 & 72 & 204 & 0 & 7 & 19 & 38 & 35 & 100 \\
\hline \multicolumn{13}{|c|}{ Inisiatif } \\
\hline 10 & 0 & 10 & 2 & 25 & 14 & 51 & 0 & 20 & 4 & 49 & 27 & 100 \\
\hline 11 & 0 & 4 & 7 & 19 & 21 & 51 & 0 & 8 & 14 & 37 & 41 & 100 \\
\hline 12 & 0 & 2 & 15 & 17 & 17 & 51 & 0 & 4 & 29 & 33 & 33 & 100 \\
\hline 13 & 0 & 0 & 7 & 23 & 21 & 51 & 0 & 0 & 14 & 45 & 41 & 100 \\
\hline 14 & 0 & 3 & 10 & 19 & 19 & 51 & 0 & 6 & 20 & 37 & 37 & 100 \\
\hline Total & 0 & 19 & 41 & 103 & 92 & 255 & 0 & 7 & 16 & 40 & 36 & 100 \\
\hline \multicolumn{13}{|c|}{ Tanggung Jawab } \\
\hline 15 & 0 & 6 & 6 & 14 & 25 & 51 & 0 & 12 & 12 & 27 & 49 & 100 \\
\hline 16 & 0 & 0 & 12 & 23 & 16 & 51 & 0 & 0 & 24 & 45 & 31 & 100 \\
\hline 17 & 0 & 3 & 5 & 14 & 29 & 51 & 0 & 6 & 10 & 27 & 57 & 100 \\
\hline 18 & 0 & 3 & 9 & 24 & 15 & 51 & 0 & 6 & 18 & 47 & 29 & 100 \\
\hline 19 & 0 & 4 & 7 & 19 & 21 & 51 & 0 & 8 & 14 & 37 & 41 & 100 \\
\hline Total & 0 & 16 & 39 & 94 & 106 & 255 & 0 & 6 & 15 & 37 & 42 & 100 \\
\hline
\end{tabular}

Dari tabel 4 terlihat jelas bahwa prestasi kerja pada indikator kualitas kerja menunjukkan $9 \%$ responden menjawab tidak setuju, $13 \%$ menjawab ragu-ragu, $48 \%$ menjawab setuju dan $31 \%$ menjawab sangat setuju. Prestasi kerja pada indikator kuantitas kerja menunjukkan $7 \%$ responden menjawab tidak setuju, 19\% responden menjawab ragu-ragu, 38\% responden menjawab setuju dan 35\% menjawab sangat setuju. Pada indikator inisiatif menunjukkan 7\% menjawab tidak setuju, 16\% menjawab ragu-ragu, 40\% menjawab setuju dan $36 \%$ menjawab sangat setuju. Pada indikator tanggung jawab menunjukkan $6 \%$ responden menjawab tidak setuju, 16\% menjawab ragu-ragu, $37 \%$ menjawab setuju dan $42 \%$ menjawab sangat setuju. 


\section{PEMBAHASAN}

Hasil analisis menunjukkan semua Hipotesis Alternatif $(\mathrm{Ha})$ yang diajukan terbukti kebenarannya, baik secara parsial maupun secara simultan. Adapun gambaran hubungan tingkat pengaruh antar variabel dapat dilihat pada gambar 1.

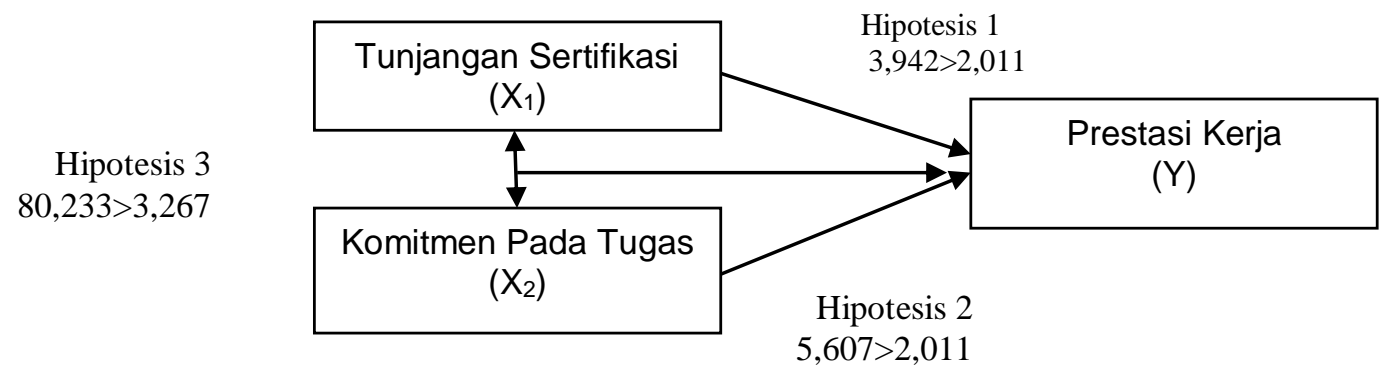

Gambar 1. Hubungan Pengaruh Tiap Variabel

\subsection{Pengaruh tunjangan sertifikasi terhadap prestasi kerja guru}

Dari hasil penelitian memperlihatkan bahwa sertifikasi guru berpengaruh signifikan terhadap prestasi kerja. Hasil ini mendukung hipotesis yang diajukan di mana sertifikasi gurui berpengaruh signifikan terhadap prestasi kerja. Menurut hasil perhitungan berdasarkan persamaan regresi bahwa jika nilai sertifikasi guru $\left(\mathrm{X}_{1}\right)$ meningkat 1 unit skor, maka prestasi kerja (Y) akan meningkat sebesar 3,872, 1 unit skor dengan ketentuan nilai sertifikasi guru $\left(\mathrm{X}_{1}\right)$ konstan. Mengenai ada tidaknya pengaruh yang signifikan antara sertifikasi guru $\left(\mathrm{X}_{1}\right)$ terhadap prestasi kerja $(\mathrm{Y})$ dapat dilihat pada besarnya nilai $t_{\text {hitung }}$ yang terdapat pada tabel 4.13. Nilai thitung sertifikasi guru sebesar 3,942 dengan signifikan sebesar 0,000 ( $\mathrm{p}<0,05)$ dengan $\mathrm{t}_{\text {tabel }}$ sebesar 2,011 atau dengan kata lain $\mathrm{f}_{\text {hitung }}$ $>\mathrm{f}_{\text {tabel}}$, maka menolak $\mathrm{H}_{0}$ dan menerima $\mathrm{H}_{\mathrm{a}}$ atau dengan kata lain hal ini menunjukkan ada pengaruh yang signifikan antara variabel sertifikasi guru $\left(\mathrm{X}_{1}\right)$ terhadap prestasi kerja (Y).

Hasil penelitian ini sejalan dengan temuan Lesy Gustina (2016) Hasil perhitungan korelasi antarvariabel menunjukkan bahwa terdapat hubungan yang signifikan antara sertifikasi guru dengan kinerja guru. Secara keseluruhan arah hubungan antara kedua variabel tersebut positif. Hal ini menunjukkan bahwa semakin tinggi nilai sertifikasi guru maka semakin tinggi pula nilai kinerja guru. Besarnya korelasi antara variabel sertifikasi guru dengan variabel kinerja guru adalah 0,816. Besarnya pengaruh antara variabel sertifikasi guru terhadap variabel kinerja guru adalah 0,678 atau sama dengan $67,8 \%$. 
Maka dapat disimpulkan bahwa terdapat pengaruh antara sertifikasi guru terhadap kinerja guru.

Tilaar (2015) menyebutkan, seorang guru profesional: (1) mempunyai dasar keilmuan yang kuat, yakni guru yang dapat mengantarkan peserta didik mengarungi dunia ilmu pengetahuan dan teknologi; (2) menguasai kiat-kiat profesi berdasarkan riset dan praksis pendidikan; (3) pengembangan profesional yang berkesinambungan karena praksis pendidikan terus menerus terjadi dan unik bagi setiap individu; (4) mempunyai kepribadian yang matang dan berkembang/mature and developing personality. Secara lebih rinci, menggambarkan guru profesional adalah guru yang memiliki: (1) kematangan pribadi, percaya diri, dapat dipercaya dan respek pada orang lain; (2) kemampuan berpikir analitis dan konseptual; (3) kemampuan perencanaan dan ekspektasi, inisiatif, dan senantiasa melakukan perbaikan; (4) memiliki jiwa kepemimpinan seperti fleksibilitas, mengelola siswa secara akuntabel dan cinta belajar; dan (5) hubungan dengan orang lain seperti bekerja di dalam tim dan memahami orang lain.

Profesionalitas guru dalam praksisnya, paling tidak dibuktikan dengan dua hal. Pertama, pemilikan kualifikasi akademik, minimum berlatar pendidikan jenjang SI-D4, dan Kedua, Pengakuan atas kedudukan guru sebagai tenaga profesional yang dibuktikan dengan sertifikasi (pemberian sertifikat pendidik). Pengakuan tersebut berfungsi mengangkat martabat dan peran guru Untuk dapat berkinerja dengan baik, pegawai harus memiliki kemampuan untuk bekerja. Ia harus memiliki motivasi, kapasitas atau kecakapan bekerja (kepribadian, kemampuan, dan keterampilan) sesuai karakteristik pekerjaan yang menjadi tanggung jawabnya. Kapasitas kerja seseorang sangat dipengaruhi berbagai faktor, diantaranya adalah (1) sumber motivasi pegawai, (2) penetapan pekerjaan, (3) gaya manajemen, dan (4) iklim organisasi. Seorang pegawai berkinerja baik, tidak hanya ditentukan oleh faktor internal individu (motivasi, persepsi, penguasaan substansi dan keterampilan teknikal), tapi juga sangat dipengaruhi faktor eksternal, terutama yang berasal dari organisasi tempat bekerja, seperti ketepatan penugasan, sikap pimpinan, sistem kerja organisasi dan kesempatan/peluang untuk melakukan pekerjaan secara optimal.

Pelaksanaan Sertifikasi Guru merupakan salah satu implementasi dari Undangundang Nomor 14 Tahun 2005 tentang Guru dan Dosen. Agar sertifikasi guru dapat direalisasikan dengan baik perlu pemahaman bersama antara berbagai unsur yang terlibat, 
baik di pusat maupun di daerah. Oleh karena itu, perlu ada koordinasi dan sinkronisasi pelaksanaan sertifikasi agar pesan Undang-Undang tersebut dapat dilaksanakan sesuai dengan harapan. Berdasarkan amanat UU No. 20 Tahun 2003 Pasal 42 dan 61, UU No. 14 Tahun 2005 Pasal 8, dan PP No.19 Tahun 2005 Pasal 29, guru pada jenis dan jenjang pendidikan anak usia dini, pendidikan dasar, dan pendidikan menengah wajib memiliki kualifikasi akademik minimal S1 atau D IV sesuai dengan bidang tugasnya, sehat jasmani dan rohani, serta memiliki kemampuan untuk mewujudkan tujuan pendidikan nasional. Di samping persyaratan tersebut, seorang guru harus memiliki kompetensi sebagai agen pembelajaran yang meliputi kompetensi pedagogi, kompetensi kepribadian, kompetensi profesional, dan kompetensi sosial.

Keempat kompetensi tersebut tercermin secara integratif dalam kinerja guru dan dibuktikan dengan sertifikat pendidik yang diperoleh melalui uji kompetensi. Sertifikasi pendidik bagi guru dalam jabatan dilaksanakan melalui penilaian portofolio dan jalur pendidikan. Penetapan peserta sertifikasi melalui penilaian portofolio berdasarkan pada urutan prioritas masa kerja sebagai guru, usia, pangkat/golongan, beban mengajar, tugas tambahan, dan prestasi kerja. Dengan persyaratan tersebut diperlukan waktu yang cukup lama bagi guru muda yang berprestasi untuk mengikuti sertifikasi. Oleh karena itu, perlu dilaksanakan sertifikasi guru dalam jabatan yang mampu mengakomodasi guru-guru muda berprestasi yaitu melalui jalur pendidikan. Pelaksana sertifikasi melalui jalur pendidikan ini adalah LPTK yang ditunjuk sesuai keputusan Mendiknas No. 122/P/2007. Mengingat pelaksanaan program sertifikasi guru dalam jabatan melalui jalur pendidikan ini melibatkan berbagai institusi terkait dan dalam upaya melakukan penjaminan mutu maka diperlukan pedoman penyelenggaraan.

\subsection{Pengaruh komitmen pada tugas terhadap prestasi kerja guru}

Dari hasil penelitian memperlihatkan bahwa komitmen pada tugas berpengaruh signifikan terhadap prestasi kerja. Hasil ini juga mendukung hipotesis yang diajukan di mana komitmen pada tugas berpengaruh signifikan terhadap prestasi kerja. Hasil regresi yang didapat bahwa jika nilai perolehan komitmen pada tugas $\left(\mathrm{X}_{2}\right)$ meningkat 1 unit skor, maka prestasi kerja (Y) akan meningkat sebesar 0,566 unit skor, dengan ketentuan nilai komitmen pada tugas $\left(\mathrm{X}_{2}\right)$ konstan. Mengenai ada tidaknya pengaruh yang signifikan, dapat dilihat pada tabel 4.13 dengan nilai thitung perolehan komitmen pada tugas $\left(\mathrm{X}_{2}\right)$ 
sebesar 5,607 dengan tingkat signifikan 0,001 ( $\mathrm{p}<0,05)$, maka menolak $\mathrm{H}_{0}$ hal ini menunjukkan ada pengaruh yang signifikan antara komitmen pada tugas $\left(\mathrm{X}_{2}\right)$ terhadap prestasi kerja $(\mathrm{Y})$. Ini menunjukkan bahwa komitmen pada tugas $\left(\mathrm{X}_{2}\right)$ berpengaruh terhadap prestasi kerja (Y).

Hal ini sejalan dengan Didik Hadiyatno dan Wiwik Saraswati (2017), Pengaruh Komitmen Pegawai (X1) terhadap variabel Prestasi Kerja pegawai (Y) dengan hasil secara parsial variabel Komitmen Pegawai (X1) tidak terbukti mempunyai pengaruh terhadap variabel Prestasi Kerja pegawai (Y) Kantor Pelayanan Pajak Pratama Balikpapan dengan koefisien korelasi parsialnya (r) sebesar 0,067 dan koefisien determinai parsial ( $\mathrm{r} 2$ ) 0,047 dengan pengujian signifikasi $\mathrm{f}_{\text {hitung }} 0,471<\mathrm{f}_{\text {tabel }}=1,96$ pada sig 0,640>0,05 berarti menunjukkan pengaruhnya yang tidak signifikan terhadap variabel Prestasi Kerja pegawai (Y) Kantor Pelayanan Pajak Pratama Balikpapan. Komitmen organisasi menyiratkan hubungan pegawai dengan organisasi secara aktif komitmen kerja karyawan menentukan berhasil tidaknya tujuan yang hendak dicapai oleh suatu organisasi atau perusahaan. bahwa komitmen karyawan terhadap organisasi merupakan sebuah proses berkesinambungan dan merupakan sebuah pengalaman individu ketika bergabung dalam sebuah organisasi. Hasil penelitian ini tidak sesuai dengan hasil penelitian terdahulu yang dilakukan oleh Kenly Rimpulaeng dan Jantje L. Sepang (2014) , Achmad Sudiro (2008) di mana pada penelitiannya menghasilkan pengaruh yang signifikan dan positif.

Putri Amanda Ratriati (2019), Berdasarkan hasil analisis dan pembahasan yang telah dilakukan maka diperoleh kesimpulan bahwa variabel komitmen organisasi, motivasi, dan pengalaman kerja memiliki pengaruh positif signifikan terhadap variabel prestasi kerja , hal ini berarti seluruh hipotesis diterima. Nilai adjusted $R$ square sebesar 71,5\% jadi masih ada 28,5\% dipengaruhi faktor lain di luar penelitian. sampel penelitian ini adalah satu perusahaan saja, dengan sampel seperti ini tentu tidak akan dapat dilakukan generalisasi bahwa penelitian dengan variabel yang sama dengan subyek yang lebih beragam akan memberikan hasil dan temuan-temuan yang sama pula. Peneliti selanjutnya disarankan dapat memperluas obyek penelitian yaitu lebih dari satu dapat dilakukan seKarisidenan Surakarta, agar hasil penelitian dapat digeneralisasi untuk ruang lingkup yang lebih luas sehingga dapat memperkuat validitas eksternal yang dibutuhkan untuk penelitian lebih lanjut. Ini bertujuan agar dapat menambah variabel selain komitmen 
organisasi, motivasi dan pengalaman kerja agar lebih memahami variabel-variabel yang mempengaruhi prestasi kerja karyawan, antara lain kemampuan kerja, komunikasi, semangat kerja, lingkungan kerja, karakteristik pekerjaan, dan lain-lain.

Faustyna (2014), Komitmen seseorang terhadap tugas merupakan aspek yang sangat penting, karena seseorang yang memiliki komitmen akan memiliki loyalitas yang tinggi, baik kepada tugas, pada pimpinan maupun organisasinya (Glesser dalam Hoy dan Miskel dalam Nellitawati, 2008). Komitmen menurut Nawawi dan Martini dalam Nellitawati (2008) merupakan suatu keputusan atau perjanjian seseorang dengan dirinya sendiri untuk melakukan atau tidak melakukan, berhenti atau meneruskan suatu perbuatan atau kegiatan. Selanjutnya Sahertian dalam Nellitawati (2008) komitmen adalah kecenderungan dalam diri seseorang untuk merasa terlibat aktivitas dengan penuh rasa tanggung jawab. Tampak suatu hubungan antara komitmen pada tugas dan kinerja karyawan, tetapi hubungan tersebut sangat sederhana. Pada umumnya, tampak bahwa komitmen afektif memiliki hubungan yang lebih erat dengan hasil-hasil organisasi seperti kinerja karyawan dan perputaran karyawan bila dibandingkan dengan dua dimensi komitmen lainnya.

\subsection{Pengaruh tunjangan sertifikasi guru dan komitmen pada tugas terhadap prestasi kerja guru}

Dari hasil penelitian memperlihatkan bahwa sertifikasi guru dan komitmen pada tugas berpengaruh signifikan terhadap prestasi kerja. Hasil ini mendukung hipotesis yang diajukan di mana sertifikasi guru dan komitmen pada tugas berpengaruh signifikan terhadap prestasi kerja.

Dengan mengambil taraf signifikan sebesar 0,004 ( $\mathrm{p}<0,05)$, maka $\mathrm{H}_{0}$ ditolak dan $\mathrm{H}_{\mathrm{a}}$ diterima, hal ini dapat dilihat dari uji $\mathrm{F}$ yang dilakukan di mana $\mathrm{t}_{\text {hitung }}$ sebesar 80,233 $>t_{\text {tabel }}$ sebesar 3,267. Artinya dapat disimpulkan bahwa ada pengaruh secara simultan antar sertifikasi guru dan komitmen pada tugas terhadap prestasi kerja serta menunjukkan hubungan positif antara sertifikasi guru dan komitmen pada tugas terhadap prestasi kerja. Hal ini menunjukkan bahwa variabel sertifikasi guru dan komitmen pada tugas mempengaruhi prestasi kerja secara bersama-sama.

Hal ini sejalan dengan hasil penelitian Purnama Sejati (2016) Berdasarkan hasil dan pembahasan penelitian yang telah dikemukakan pada Bab sebelumnya, maka dapat 
diambil kesimpulan sebagai berikut: 2 . Hasil analisis data variabel motivasi kerja yang dilakukan menghasilkan rata-rata hitung sebesar 78,04. Apabila diinterpretasikan dengan rata-rata ideal termasuk dalam kategori tinggi. Hasil tersebut menunjukkan bahwa guru dan karyawan di SMK Muhammadiyah 1 Sleman mempunyai motivasi kerja dalam kategori tinggi. 3. Hasil analisis data prestasi kerja yang dilakukan menghasilkan rata-rata hitung sebesar 77,73, apabila diinterpretasikan dengan rata-rata ideal termasuk dalam kategori tinggi. Hasil tersebut menunjukkan bahwa guru dan karyawan di SMK Muhammadiyah 1 Sleman mempunyai prestasi kerja dalam kategori tinggi. 4. Terdapat hubungan motivasi kerja dengan prestasi kerja guru dan karyawan dengan nilai koefisien korelasi (r hitung) sebesar 0,510, yang termasuk dalam kategori cukup kuat. 5. Variabel motivasi kerja memberikan sumbangan (kontribusi) terhadap prestasi kerja guru dan karyawan sebesar 26,01\%. Sedangkan sisanya yaitu sebesar 73,99\% ditentukan oleh variabel lain yang tidak diteliti dalam penelitian ini.

Ibnu Yarham Yamanie, Syaharuddin Y (2016) Tujuan dari penelitian ini adalah untuk menyelidiki dan mengambil fokus pada pengaruh penilaian prestasi kerja komitmen organisasi dan disiplin kerja yang bertanggung jawab terhadap kinerja karyawan untuk PT. Pelindo IV Samarinda. Sampel yang digunakan dalam penelitian ini adalah kerja 51 karyawan di kantor berdasarkan metode sensus atau seluruh populasi sebagai besar sampel. Dalam rangka memfasilitasi pemecahan masalah, penelitian ini dilakukan dengan menggunakan metode analisis regresi linier dengan bantuan Statistik Produk dan Layanan Solusi (SPSS) 16 for Windows. Hasil penelitian ini adalah: Pengaruh penilaian prestasi kerja, komitmen organisasi dan disiplin kerja memiliki pengaruh positif terhadap kinerja karyawan. Saran untuk penelitian lebih lanjut, Anda harus mampu meningkatkan kualitas penelitian yang lebih baik dan dapat menambah dan memperluas ruang lingkup dari sampel penelitian.

Sedangkan penilaian pelaksanaan pekerjaan atau penilaian prestasi kerja (appraisal of performance) adalah suatu sistem yang digunakan untuk menilai dan mengetahui apakah seorang karyawan telah melaksanakan pekerjaannya masing-masing secara keseluruhan. Dalam hal ini, pelaksanaan pekerjaan secara keseluruhan bukan berarti hanya dilihat/dinilai hasil fisiknya saja tetapi meliputi berbagai hal seperti kuantitas kerja, kualitas kerja, disiplin, kerja sama, tanggung jawab, kesetiaan, kejujuran, dan loyalitas (Soeprihanto, 2000:7). Menurut Sikula dalam Hasibuan (2009:86) Penilaian 
prestasi kerja adalah evaluasi yang sistematis terhadap pekerjaan yang telah dilakukan oleh karyawan dan ditujukan untuk pengembangan.

Komitmen organisasi (organizational commitment) merupakan salah satu tingkah laku dalam organisasi yang banyak dibicarakan dan diteliti, baik sebagai variabel terikat, variabel bebas, maupun variabel mediator. Hal ini antara lain dikarenakan organisasi membutuhkan karyawan yang memiliki komitmen organisasi yang tinggi agar organisasi dapat terus bertahan serta meningkatkan jasa dan produk yang dihasilkannya Beberapa ahli mendefinisikan komitmen organisasional karyawan sebagai berikut: 1. Mathis and Jackson dalam Sopiah (2008:155) memberikan definisi "Organizational Commitment is the degree to which employees believe in and accept organizational goals and desire to remain with the organization (komitmen organisasional adalah derajat yang mana karyawan percaya dan menerima tujuan-tujuan organisasi dan akan tetap tinggal atau tidak akan meninggalkan organisasi)". 2. Mowday dalam Sopiah (2008:155) menyebut komitmen kerja sebagai istilah lain dari komitmen organisasional. Menurut dia, "komitmen organisasional merupakan dimensi perilaku penting yang dapat digunakan untuk menilai kecenderungan pegawai. Komitmen organisasional adalah identifikasi dan keterlibatan seseorang yang relatif kuat terhadap organisasi.

\section{SIMPULAN}

Berdasarkan hasil analisis data, maka dapat disimpulkan bahwa Hipotesis alternatif yang berbunyi ada pengaruh sertifikasi guru terhadap prestasi kerja di SMA Negeri Tanjung Raja, terbukti kebenarannya. Hipotesis alternatif yang berbunyi ada pengaruh komitmen pada tugas terhadap prestasi kerja di SMA Negeri Tanjung Raja, terbukti kebenarannya. Serta, Hipotesis alternatif yang berbunyi ada pengaruh sertifikasi guru dan komitmen pada tugas terhadap prestasi di SMA Negeri Tanjung Raja, terbukti kebenarannya.

\section{Acknowlegement}

Jurnal ini dibuat dari tesis Evi Anggraini dengan karya sendiri dibantu oleh Dr. H. Edi Harapan, sebagai pembimbing utama, dan Dr. Tahrun, M.Pd, sebagai pembimbing pendamping. Terima kasih atas segala bimbingannya dalam penyempurnaan jurnal ini. 


\section{DAFTAR PUSTAKA}

Colquitt, J.A., Lepine, J.A., \& Wesson M.J. (2015). Organizational behavior: improving performance and commitment in the workplace 4th. USA: Mc Graw Hill Education.

Hadiyatno, D., \& Saraswati, W. (2017). Pengaruh komitmen pegawai terhadap variabel Prestasi Kantor Pelayanan Pajak Pratama Balikpapan. (Skripsi). Universitas Tanjung Pura.1

Faustyna. (2014). Pengaruh kompetensi dan komitmen organisasi pada tugas terhadap kinerja karyawan. Jurnal Manajemen \& Bisnis, 14(1). 49-63. doi: https://doi.org/10.30596/jimb.v14i01.114

Greenberg, J. (2011). Behavior in organization 10th. Prentice Hall: Pearson Education.

Hasibuan, M. (2009). Manajemen sumber daya manusia. Jakarta: Bumi Aksara.

Yamanie, I. Y., \& Syaharuddin, Y. (2016). Pengaruh penilaian prestasi kerja, komitmen organisasi dan disiplin kerja terhadap kinerja karyawan pada PT. Pelabuhan Indonesia IV cabang Samarinda. Jurnal Manajemen, 8(1). 55-65. doi: http://dx.doi.org/10.29264/jmmn.v8i1.1186

Kreitner, R., \& Kinicki, A. (2013). Organizational behavior 10th. USA: Mc Graw Hill Companies.

Gustina, L. (2016). Pengaruh sertifikasi guru terhadap kinerja guru studi pada guru tersertifikasi di SD Negeri 2 Tanjung Senang, Kelurahan Tanjung Senang, kecamatan Tanjung Senang, Bandar Lampung. (Skripsi). Universitas Lampung.

Mangkunegara. (2009). Motivasi dan Kepribadian. Jakarta: Pustaka Binaman Presido.

Marselus, R. P. (2011). Sertifikasi Profesi Guru. Jakarta: Indeks Jakarta.

Mulyasa, E. (2013). Menjadi kepala sekolah profesional. Bandung: Remaja Rosdakarya.

Muslich, M. (2009). Sertifikasi guru menuju profesionalisme pendidik. Jakarta: Bumi Aksara.

Nellitawati. (2008). Studi tentang komitmen terhadap tugas dan iklim kerja sama guru di SMP Negeri Kecamatan Koto Tangah Padang. Pakar pendidikan, 6(1), 41-55.

Purnama, S. (2016). Hubungan motivasi kerja dengan prestasi kerja guru dan karyawan di SMK Muhammadiyah 1 Sleman. (Skripsi). Universitas Negeri Yogyakata.

Ratriati, P. A. (2019) Pengaruh komitmen organisasi, motivasi, dan pengalaman terhadap prestasi kerja. (Skripsi). Universitas Muhammadiyah Surakarta.

Republik Indonesia. (2003). Undang-Undang Republik Indonesia Nomor 20 Tahun 2003 tentang Sistem Pendidikan Nasional. Jakarta: Republik Indonesia.

Republik Indonesia. (2005). Undang-Undang Republik Indonesia Nomor 14 Tahun 2005 tentang Guru dan Dosen. Jakarta: Republik Indonesia.

Saroni, M. (2011). Personal branding guru: meningkatkan kualitas dan proesionalitas guru. Yogyakarta: Ar-ruzz Media.

Sopiah. (2008). Perilaku organisasional. Yogyakarta: ANDI.

Sugiyono. (2014). Metode penelitian kuantitatif, kualitatif, dan $r \& d$. Bandung: Alfabeta.

Tilaar, H. (2015). Pendidikan kebudayaan dan masyarakat madani Indonesia. Bandung: Rosdakarya. 